\title{
Türkçede Aitlik Ulamı ve Biçimsel İfadesi
}

\author{
Aysun Kundurac1 \\ Boğaziçi Üniversitesi \\ aysun.kunduraci@boun.edu.tr
}

\begin{abstract}
Özet
$\mathrm{Bu}$ çalışma aitliğin Türkçede bir dilbilgisel ulam olduğunu ve alanyazında şimdiye dek "3. tekil kişi iyelik" eki olarak gösterilen -(s)I ekinin kişi, sayı ve aitlik yerine yalnızca aitlik ulamını gösterdiğini, diğer bir deyişle, $-(s) I$ ekinin kişi ve sayı bilgisi içermeyen bir "aitlik" eki ${ }^{1}$ olduğunu önermektedir. $-(s) I$ ekinin işlevi için önerilen çözümleme, ekin eklenme sürecini, belirdiği ortamı, iyelik öbeklerini, iyelik öbeklerinin anlamsal, yapısal ve biçimsel özelliklerini de kapsamaktadır. Önerilen çözümleme, biçimbilimi özerk bir sistem olarak kabul etmekte ve anlam ve biçimin ayrı süreçlere dayandığı bir biçimbilim modelini izlemektedir. Çalışma, ayrıca, iyelik öbeklerinde uyum ilişkisine değinmekte, sunulan önerileri desteklemek ve çalışmayı daha ilginç kılmak adına farklı dillerden veriler sunmaktadır. ${ }^{2}$
\end{abstract}

Anahtar sözcükler: Türkçe, biçimbilim, aitlik, kişi, uyum, iyelik öbekleri

\section{Konu, Amaç ve Düzenleme}

Bu çalışma Türkçede iyelik öbeklerindeki - $(s) I$ ekinin ${ }^{3}$ işlevi ve eklenme süreci üzerinedir. Çalışma bu ekin, alanyazında şimdiye dek yüklendiği "3. tekil kişi” değerlerini içeremeyeceğini savunmakta ve ekin kişi ve sayı bilgisi olmadan ait olmayı ifade ettiğini öne sürmektedir. - $(s) I$ ekinin işlevine alışılmadık bir açıdan bakan çalışma, aynı zamanda, bu ekin eklenmesini özerk bir biçimbilim dizgesinde ("autonomous morphology", bkz. Zwicky, 1986; Di Sciullo ve Williams, 1987; Aronoff, 1994; Beard, 1995; Göksel, 1998; Pounder, 2000; Sadock, 2012; Kundurac1, 2013) ve süreçsel biçimbilim çerçevesinde

1 Bu çalıșma, Türkçe alanyazınında "iyelik eki” olarak bahsedilen $-(I) m,-(I) n$ ve $-(s) I$ eklerini "aitlik eki" olarak tanımlamaktadır. Çalışmanın bu ekler için "aitlik" terimini "iyeliğe" yeğlemesinin sebebi aitliğin "ait olmayı" ve iyeliğin "sahip olmayı" vurgulaması ve aitlik eklerinin asıl işlevinin "aitlik" olduğunu gösterme çabasıdır.

$2 \mathrm{Bu}$ çalışma, TÜBİTAK tarafindan, $114 \mathrm{c} 064$ nolu proje kapsamında desteklenmektedir.

3 Bu ek Türkçenin sesdizgesel özelliklerinden dolayı $-\imath,-i,-u,-\ddot{u},-s l,-s i,-s u$, -sü ve durum çekiminden önce $-s I n$ olarak belirmekte, bu çalışmada $-(s) I$ olarak gösterilmektedir. 
("process-based morphology", bkz. Zwicky, 1986; Anderson, 1992; Aronoff, 1994; Beard, 1995; Pounder, 2000; Kunduracı, 2013) çözümlemektedir.

$-(s) I$ ekine yüklenen geleneksel 3. tekil kişi işlevinin sebebine değinen bu bölümün ardından (aşağıda), -(s)I'ya bu işlevi yüklemenin, ya da Türkçede 3 . kişi için özel bir biçimbirim olduğunu varsaymanın, doğurduğu ve açıklayamadığı sorunlara değinilmektedir (§2). Bunun ardından, §3’te, gerek ekin işlevini gerekse iyelik öbeklerindeki biçimsel türetim ve anlam oluşumunu kapsayan öneri sunulmakta; aitlik, kişi, sayı ve uyum ilişkisi ele alınmaktadır. $\mathrm{Bu}$ bölümde farklı dillerden iyelik öbeklerinin çalışma açısından önemli özelliklerine de yer verilmektedir. Bunu izleyen $§ 4$ 'te, iyelik öbekleri ve uyum ilişkisinin bazı ilginç noktaları vurgulanmaktadır. $§ 5$ 'te ise çalışmanın sav ve önerilerine dayanan, gerek Türkçe biçimbilimiyle gerekse genel olarak kuramsal biçimbilimle ilgili çıkarımlar yapılmaktadır. ${ }^{4}$

Bilindiği gibi, Türkçede iyelik öbekleri tamlayan eki taşıyan bir niteleyici/sahip öge (İng. "possessor") ve aitlik eki taşıyan bir baş/ait ögeden (İng. "possessum”) oluşur, bkz. (1). Aşağıda da görüldüğü gibi, (1c)'deki -(s)I eki (1a)'daki 1. kişi aitlik eki -(I)m (1.AİT) ve (1b)'deki 2. kişi aitlik eki -(I)n (2.AİT) ile bütünleyici bir dağılım içindedir:

(1) a. ben-im şark1-m

b. sen-in şark1-n

c. on-un şark1-s1

Bu demektir ki - $(s) I$ eki 1.AİT ve 2.AİT ekleriyle yan yana oluşamaz, bkz. (2):

(2) a. ben-im * şark1-s1-m

b. sen-in * şark1-s1-n

(2)'deki dilbilgisidışı durum, yani $-(s)$ I'nın 1.AİT ve 2.AİT ekleriyle bütünleyici dağılım içinde olması, -(s)I'nın önceki çalışmaların hemen hemen hepsinde "3. tekil kişi (iyelik) eki” olarak tanımlanmasına sebep olmuştur (örn. Lewis, 1967, 2000; Underhill, 1976; van Schaaik, 1996; Kornfilt, 1997; Göksel ve Kerslake, 2005). Buradaki önemli nokta şudur: Alanyazında olduğu gibi $(s) I$ 'ya “3. tekil kişi”" bilgisini atfetmek bu ekin bir uyum eki olduğu anlamına gelmektedir, buna göre iyelik öbeklerindeki baş, kişi ve sayı açısından niteleyici ögeyle uyum göstermektedir (örn. bkz. Arslan-Kechriotis, 2006, s. 126). Bu çalışma, $-(s) I^{\prime}$ yı bir kişi ve sayı uyum eki yapan bu görüşün aksine,

4 Çalışmada kullanılan kısaltmalar şu şekildedir: 1: 1. Kişi, 2: 2. Kişi, 3: 3. Kişi, AİT: aitlik, AK: anlamsal kural, AÖ: ad öbeği, BK: biçimsel kural, Kk: kural koşulu, OP: operasyon, OPk: operasyon koşulu, TAM: tamlayan durumu, TEK: tekil, Tk: taban koşulu, YAL: yalın durum. 
Türkçenin belirli biçimbilimsel özelliklerine dayanarak, $-(s) I$ 'nın Türkçede bir uyum eki olamayacağını göstermektedir. §2 bu gerekçeleri tek tek ele almaktadir.

\section{Biçimbilimsel Sorunlar}

Bu bölümde - $(s) I$ ekinin kişi ve sayı ulamlarına ait değerler (' 3 ', 'tekil') taşıyıp taşımadığı irdelenmekte ve bu ekin aslında bu ulamlara ait değerler taşımadığı savunulmaktadır. Çalışmanın savının dayandığı ilk nokta $-(s) I$ ekinin 1 .AİT ve 2.AİT ekleriyle, yukarıda $(1,2)$ 'de gösterildiği gibi, bütünleyici bir dağılım içinde olmasına rağmen, biçimbilimsel olarak bu eklerden farklı bir davranış ve dağılım sergilemesidir. Aşağıda, ilginç bir şekilde, $-(s) I$ 'nın aksine, 1.AİT/2.AİT eklerinin kimi türetim eklerinden hemen önce eklenebildiğini görüyoruz:

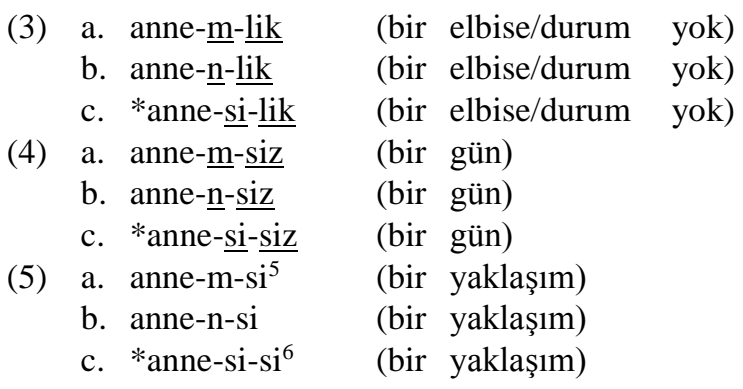

(3), (4) ve (5) bize 1.AİT/2.AİT eklerinin çekim ekleri olsalar da kimi türetimlerden önce eklenebildiğini, ancak $-(s) I$ ekinin bu ortamlarda oluşamadığını göstermektedir. ${ }^{7}$ Benzer bir şekilde, 1.AİT/2.AİT ekleri çoğul eki -lAr'dan önce de eklenebilir, yine, - $(s) I$ 'nın aksine:

\footnotetext{
5 (5a)'daki biçim anne+(I)msI yapısını içerseydi 'anne gibi' anlamına gelerek genel gönderimli olacaktı ancak burada bahsedilen yap1 anne $+m+s i$ olduğundan '(benim) anneminki gibi' anlamına gelmektedir.

6 (4c) ve (5c)'de izin verilmeyen $*_{-s I-s I}$ ve $*_{s I-s I z}$ dizilerinin hece yitimiyle bir ilgisi yoktur çünkü Türkçe sesbilimsel benzerliğe ancak biçimbilimsel farklılığa sahip birimlerin yan yana dizilmesine izin verir, örn. konuş- $\underline{m a}-\underline{m a}$ (örneğin bkz. Haig 2004).

7 Ancak, -gil eki bu duruma bir istisna gibi görünmektedir: Diğer türetim eklerinin aksine -(s)I -gil'den önce eklenebilir, örn. anne-si-gil. Yine de bu durum (3), (4) ve (5)’teki uyuşmazlığı açıklamaya yetmemektedir.
} 
(6) a. anne- $\underline{\mathrm{m}}-\underline{\mathrm{ler}}$

b. anne-n-ler

c. *anne-si-ler

(3-6)'daki ifadelerle -(s)I ekinin 1.AİT/2.AİT ekleriyle aynı dizilde olmasına rağmen, biçimbilimsel diğer ortamlarda ayırt edici bir özelliğe sahip olduğunu görüyoruz: 1.AİT/2.AİT ekleri aynı dağılımı gösterirken $-(s) I$ farklıdır ve bu farklılık bir açıklama gerektirmektedir. Daha açık olmak gerekirse, bu üç ek aynı konuma $^{8}$ ve göreve sahipse, neden yalnızca $-(s) I$ 'nın farklı bir dağılım gösterdiği açıklanmalıdır. ${ }^{9}$

Çalışmanın savının dayandığı ikinci nokta iyelik öbeklerinde sayı çekimiyle ilgilidir: 1. ve 2. kişiyi içeren iyelik öbeklerinde ait öge, sayı ulamı açısından sahip ögeyle zorunlu olarak uyum içindedir, bkz. (7):

(7) a. biz-im şark1-m*(-1z)

b. $\underline{\text { siz-in }}$ şark1-n*(-1z)

(7)'deki ifadelerdeki önemli nokta şudur: İyelik öbeklerindeki sahip öge çoğul değeri taşıdığında, yani biz, siz olduğunda, öbeklerdeki ait ögeler de (yukarıda şarkı) zorunlu olarak bu değeri taşımaktadır. Diğer bir deyişle, (7)'deki gibi öbeklerde sayı uyumu zorunludur ve ilginçtir ki bu sayı uyumu Türkçede kişi ulamına özgü bir sayı uyum ekiyle kodlanmaktadır: $-I z$. Yukarıda vurgulandığı gibi $-I z$ eki çoğul niteleyiciler varken zorunlu olarak öbek başında 1.AİT/2.AİT eklerinin ardından belirdiğinden, bu eki tek bir "kişi-çoğulu" (kişiye özgü çoğul) biçimbirimi olarak tanımlamak yerinde olacaktır.

-Iz'1, -ImIz/-InIz biçimbirimlerine ait bağımlı bir biçim yerine ${ }^{10}$ kişi ulamına özgü çoğulluk gösteren, tek, ayrı bir biçimbirim olarak kabul etmek tipolojik bir açıdan da önemlidir. ${ }^{11}$ Örneğin, Cysouw (2011) kişi ulamına özgü çoğul eklerinin, hem anlamsal hem de biçimbilimsel yönden, sıradan çoğul eklerinden farklı olduğunu göstermektedir.

-Iz ekinin bu çalışma açısından önemi ise en iyi şu şekilde anlatılabilir: Bu ek çoğul sahipler içeren iyelik öbeklerinde yalnızca 1. ve 2. kişiyle

\footnotetext{
8 Bu çalışmada "konum", İng. "slot” terimi için kullanılmaktadır.

9 Bu konuyla ilgili şu tarihsel noktaya da değinmek gerekir: Tarihsel olarak diğer kişi ekleri kişi adıllarının kaynaşması olarak kabul edilirken $-(s) I$ potansiyel $o(l)$ biçiminin kaynaşması değildir (bu konuyu hatırlatan eleştirmene teşekkür ederim). Ayrıca, $o(l)$ biçimi aslında kişi adılı yerine kullanılan bir gösterme adılıdır. Bu noktalar da yine Türkçenin 3. kişiyi biçimbilimsel olarak göstermeme eğilimini yansıtmaktadır.

10 Örneğin, bkz. Lewis, 2000, s. 37; Hankamer, 2011.

11 -Iz'ın aynı işlevle çekimli yüklemlerde de belirdiğini hatırlatmakta yarar vardır: konuş-tu-n ve konuş-tu-n-uz.
} 
belirmektedir, yani ait ögelerde 1.AİT ve 2.AİT eklerinden sonra zorunludur. Buna karşın, 3. kişiyi içeren bir iyelik öbeği çoğul sahip içerse de $-I z,-(s) I$ ekinin ardından eklenemez, bkz. (8):

(8) onlar-1n çanta-sil $(*-\underline{z})$

(8)'deki ifadenin biçimi (7)'dekilerle ters düşmektedir: Kişi-çoğulu -Iz ekinin (I) $m$ ve $-(I) n$ 'dan sonra yokluğu dilbilgisidışıyken $(7),-(s) I$ 'dan sonra varlığ dilbilgisidışıdır (8). Belki bundan daha da önemli diğer bir nokta da, 3. kişili çoğul sahipteki çoğulluğun (yukarıda onlar), -Iz'dan başka herhangi bir ekle de gösterilememesidir. Aşağıda (9)'daki ifadelerle bu nokta daha da belirginleşmektedir:

(9) a. on-un şark1-s1

b. onlar-1n şark1-s1

(9a)'daki iyelik öbeği tekil bir sahip (o), (9b)'deki ise çoğul bir sahip (onlar) içermektedir. Bununla beraber, (9b)'deki çoğulluk ait ögede (şarkı) herhangi bir şekilde, örneğin $-I z$ ya da başka bir ekle, gösterilmemektedir. Bu da şu anlama gelmektedir: Türkçede 3. kişili iyelik öbekleri, 1. ve 2. kişililerin aksine, sayı uyumu taşımamaktadır. Sahip ögedeki çoğulluk değeri, yalnızca 1. ve 2. kişili öbeklerde ait ögeye yansımaktadır (-Iz ekiyle).

Bu konuyla ilgili olarak akıllara şöyle bir soru gelebilir: Aşağıda (10a)'daki gibi bir ifadede yukarıda bahsedilen çoğulluk -lAr ekiyle gösterilemez mi?

(10) a. onlar-1n şark1- $\underline{\text { lar-1 }}$

$\rightarrow$ birden çok varlik

b. on-un şark1- $\underline{\text { lar-1 }}$

Yani, 1. ve 2. kişili öbeklerde $-I z$ ekinin gördüğü işlevi, (10a)'daki gibi 3. kişili öbeklerde -lAr eki üstlenemez mi? Cevabımız hayır, çünkü (10a)'da ait ögede oluşan -lAr, sahip ögeyle sayı uyumu değil, aynen (10b)'deki gibi ait ögenin göndergesinin çoğul olduğunu gösterir. Diğer bir deyişle, (10a)'daki ifade, (7)'deki bizim/sizin şarkl- $m / n-l z$ ifadelerinin aksine, tek bir varlığa gönderim yapamaz ve bu da (10a)'daki iyelik öbeklerinde -lAr'ın uyum eki değil, yalnızca çoğul eki olduğunu göstermektedir. ${ }^{12}$

12 Bu sebeple bu çalışmada, örneğin Kornfilt (1984a; 1997, s. 384) ve Lewis'in (2000, s. 37) aksine, iyelik öbeklerinde -lArI şeklinde bir 3. kişi çoğul eki kullanıldığı varsayılmamaktadır. Aksi takdirde, (10a)'nın tekil okumaya izin vermeyişini açıklayamazdık. Bu da iyelik öbeklerinde "3. kişi çoğul” için özel bir ek olmadığı ve $l A r$ 'ın yalnızca çoğul ait ögeler için kullanıldığı anlamına gelmektedir. Ancak şöyle bir soruna da değinmeden geçemeyiz: İlginçtir ki -lAr eki iyelik öbeklerinin dışındaki kimi ortamlarda sayı uyumunu gösterebilmektedir. Örneğin, öğrenciler ve hoca-lar-l 
Çalışmanın savını destekleyen son nokta da Türkçe biçimbiliminin 3. kişi değerine karşı genel davranışıdır: bu değeri göstermemek. Türkçede uyum ilişkisi gösteren diğer bir dilbilgisel alan olan çekimli yüklemlerde 3. kişi, 1. ve 2. kişinin aksine, herhangi bir ekle ifade edilmemektedir. Aşağıda (11)'de de görüldüğü gibi, yüklem ister ad ister eylem kökenli olsun, 1. ve 2. kişi ekleri tabanlara zorunlu olarak eklenirken, 3. kişi için herhangi bir işaretleme yoktur: ${ }^{13,14}$

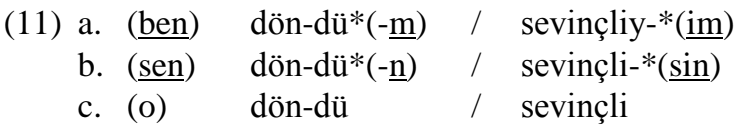

(11c)'nin $(11 \mathrm{a}, \mathrm{b})$ ile ters düşmesinin çalışma açısından önemi Türkçede kişi ulamındaki değerlerden birinin ('3'), bu değerlerin zorunlu olarak gösterildiği bir alanda göterilmemesidir. Bu değerin, '3', çekimli yüklemlerde görünmeyip yalnızca (1c)'deki gibi iyelik öbeklerinde görünmesi sorunlu bir durumdur, çünkü, beklenmediktir. Siewierska'nın (2004) geniş kapsamlı tipolojik çalışmasına göre kişi uyumu yüklemlerde iyelik öbeklerine göre çok daha yüksek bir olasılıkla görülür. Siewierska'nın kişi uyumunun temel hedeflerini gösteren hiyerarşisinde önce yüklemler, daha sonra ait adlar, son olarak da ilgeçler gelmektedir: yüklemler $>$ ait adlar > ilgeçler (2004, s. 127). ${ }^{15}$ Siewierska bu hiyerarşinin hem dillerarası açıdan hem de bir dilin kendi içindeki dizgesinde geçerliliği olduğunu vurgulamaktadır (s. 128). Buna göre, ait adlarda kişi ekinin varlığı bu ekin yüklemlerde de kodlanıyor olmasını gerektirir. Bu durumda bir kişi değerinin ikinci sırayı alan ait adlarda (iyelik öbeklerindeki başlar) gösterilip ilk sırayı alan yüklemlerde gösterilmemesi, yani Türkçede olduğu varsayılan durum, pek de beklendik değildir. Hiyerarşiye göre

ifadesinde anlamsal belirsizlik vardır: Tek bir hocadan da birden çok hocadan da bahsediliyor olabilir, ki ilk durumda - $l A r$ sayı uyumunu gösterecektir. Bununla birlikte, yukarıda da belirtildiği gibi iyelik öbeklerinde (yani sahip öge dilbilgisel ortamda varken) -lAr'lı tekil okuma mümkün değildir, bkz. (10a). ögrenciler ve hoca-lar-l gibi ifadelerde -lAr'ın, iyelik öbeklerinin aksine, uyum gösterebiliyor olması açıklanmayı beklemekle beraber, bu çalışmanın kapsamı dışındadır.

13 İstisna durum: Emir kipinde 3. kişi kodlanmaktadır (ve bu biçim zaman zaman dilek kipinde de kullanılmaktadır, örn. bit-sin (bkz. Kornfilt, 1997, s. 369-373)). Ancak kanımca, emir kipindeki özel durum 3. ve 2. kişiyi biçimsel ve anlamsal olarak ayırt etme gereksiniminden kaynaklanmaktadır.

14 Konuyla ilgili önceki bir çalışmada (Uzun, 2002), Türkçede kişi ayrımının ikili olduğu ve 3. kişinin diğer iki kişiye bütüncül karşıtlık içinde sıfır biçimcik olarak belirlendiği savunulmaktadır.

$15 \mathrm{Bu}$ hiyerarşiyi destekleyen istatiksel veri, tablo ve diğer çalışmalar için bkz. Siewierska 2004 
daha olası durum, örneğin, $-(s) I$ ekinin, 3 . kişi eki olduğu takdirde, yüklemlerde belirip iyelik öbeklerindeki ait adlarda belirmeyebilmesidir, ki bu Türkçedekinin aksi olan durumdur. ${ }^{16}$ Kısaca, Türkçede 3 . kişi uyumu/gösterilmesi iyelik öbeklerinde vardır ama yüklemlerde yoktur şeklinde bir yaklaşım sorunlu görünmektedir ve bu durum bir açıklama beklemektedir.

$\mathrm{Bu}$ bölümde değinilen biçimbilimsel sorunları özetleyecek olursak karşımıza üç önemli nokta çıkar: Birincisi $-(s) I$ ekinin biçimbilimsel olarak, 1.AİT ve 2.AİT eklerinin tersine, oldukça kısıtlı bir dağılıma sahip olmasıdır (bkz. 3-8), ki bu aynı dizile ait bütünsel dağılımlı ekler için alışılmadık bir durumdur. İkinci nokta 3. kişili iyelik öbeklerinde sayı uyumunun yitik olmasıdır (bkz. 7-10). Bu noktayla ilgili olarak Türkçede kişiye özgü sayı eki olarak belirlenen $-I z$ ekinin, 1.AİT ve 2.AİT eklerinin aksine, $-(s) \Gamma$ y1 izleyememesi ve 3. kişili iyelik öbeklerinde belirememesini de hatırlamak yararlı olacaktır. Diğer bir deyişle, Türkçede iyelik öbeklerinde sayı uyumunun kişi uyumuna bağımlı olduğu, öncelikle kişi uyumunu gerektirdiği ortaya çıkmaktadır. Sonuncu nokta da yüklemlerde 3. kişi uyumunun yitik olmasıdır. $\mathrm{Bu}$ üç temel noktaya tek tek bakmak yerine hepsini birlikte değerlendirecek olursak, geleneksel tüm görüşlerin aksine, $-(s) I$ ekinin iyelik öbeklerinde " 3 . tekil kişiyi”" gösteremeyeceği sonucuna varırız. Bu ekin iyelik öbeklerinde 3 . tekil kişi yerine hangi işlevi üstlendiği aşağıda §3'te sunulmaktadır.

\section{3. Öneri}

\section{$3.1-(s) I$ 'nın İyelik Öbeklerindeki İslevi}

Bu bölümde önerilen çözümleme Kundurac1, 2013'e dayanmaktadır. Bir önceki bölümdeki veri ve tartışmalara dayanarak sunulan öneri $-(s) I$ ekinin iyelik öbeklerinde kişi ve sayı bilgisi içermeden, yalnızca "aitliği”, yani bir varlığın bir başka varlığa ait olduğunu gösterdiği şeklindedir: $-(s) I$ Türkçede kişi ve sayı değil, aitlik ekidir. Bu çözümleme $-(s) I$ 'yı aynen 1.AİT/2.AİT ekleri gibi bir çekim eki olarak kabul etmekte, ancak onlardan farklı olarak kişi bilgisi ifade etmediğini öne sürmektedir. Yani, 1.AİT ve 2.AİT ekleri hem kişi hem de aitlik ifade ederken, $-(s) I$ yalnızca aitlik ifade etmektedir. Bu öneri yalnızca $-(s) I$ 'nın neden oluştuğunu açıklamakla kalmayıp, aynı zamanda beklenilen durumlarda neden oluşmadığını ve $\S 2$ 'de ortaya atılan sorunları da çözmektedir:

(i) $-(s) I$ bir aitlik eki olduğu için iyelik öbeklerinde oluşur,

16 Siewierska, bununla beraber, kimi istisna durumların varlığından bahseder: örneğin Burmese, Kayah Li, Paiwan gibi bazı dillerde iyelik öbeklerinde kişi uyumu varken, yüklemlerde yoktur. Ancak bu dillerdeki durum yine Türkçedekinden farklı değerlendirilmelidir çünkü Türkçede yüklemlerde 1. ve 2. kişi uyumu zorunlu, 3. kişi uyumu yitiktir. 
(ii) $-(s) I$ aitlik+kişi değil yalnızca aitlik eki olmasıyla 1.AİT/2.AİT eklerinden ayrılır ve farklı bir biçimbilimsel dağılım gösterir,

(iii) 3. kişili iyelik öbeklerinde sayı uyumunun olmaması kişi uyumunun olmamasından kaynaklanır,

(iv) $-I z$ eki kişiye özgü (ya da kişi bağımlı) sayı eki olduğu için -(s)I'yla birlikte eklenemez,

(v) yüklemlerde 3. kişi değerinin gösterilmemesi bu değerin iyelik öbeklerinde de gösterilmeyeceğini öngörür.

Bu öneri §2'deki sorunları çözdüğü gibi bir başka öneriyi daha doğurmaktadır: Aitlik Türkçede aynen sayı ve kişi gibi bir dilbilgisel ulamdır ve bu ulam aitlik ekleri olan - $(s) I$, 1.AİT ve 2.AİT ekleriyle gösterilir. ${ }^{17}$ Ulamın iki değeri vardır: 'ait' (örn. şarkl-sl) ve ‘ait olmayan' (örn. şarkı). Bu çözümleme, aynı zamanda, Türkçede dilbilgisel bir olguyla da örtüşmektedir: 3. kişi için özel bir adılın olmaması ve bu boşluk için gösterme adılı "o"nun kullanılması. Bu durumun çalışma açısından önemi şudur: Eğer kişi uyumu temelde adıllar tarafindan tetikleniyorsa, örneğin Nikolaeva'nın (2005) öne sürdüğü gibi, Türkçede 3. kişi değeri için bir adılın bile olmaması bu değerin biçimbilimsel olarak da gösterilmeyeceğini öngörür.

§2'de ve bu bölümdeki tartışmaların ışı̆̆ında, yukarıda da değinildiği gibi, aslında beklenen durum 3. kişinin, diğer uyum alanında olduğu gibi, iyelik öbeklerinde de gösterilmemesi, biçimbilimsel olarak yitik olmasıdır. Bu da bizi yine iyelik öbeklerindeki $-(s) I$ 'nın kişiden bağımsız yalnızca ait olmayı gösterdiği, bir aitlik eki olduğu sonucuna ulaştırmaktadır. Eğer Türkçede 3. kişi değeri için bir ek olsaydı, bu ek $-(s) I$ 'nın oluştuğu konumda, yani aitlik/kişi eklerinin oluştuğu konumda, oluşurdu ve $-(s) I$ gibi 1 . kişi ve 2 . kişi aitlik ekleriyle (1.AİT/2.AİT) aynı dizilde yer alırdı. Kanımca, hem bu konumsal benzerlik hem de 1.AİT/2.AİT eklerinin de $-(s) I$ gibi aitliği ifade etmesi, (s)I'nın alanyazında şimdiye dek sorgulanmadan 3. kişi eki olarak yorumlanmasına sebep olmuştur. ${ }^{18}$ Aşağıda $\$ 3.2,-(s) I$ 'nın yalnızca aitlik eki olduğunu ve aitliğin Türkçede kişiden ayrı bir ulam olduğunu destekler nitelikte, farklı bir dilden veriler sunmaktadır.

17 Aitliğin bir ulam olduğu başka diller için bakınız Mel’čuk, 1994.

18 Akıllara şöyle bir soru gelebilir: O halde $-(s) I$ neden 3 . kişi yorumuna izin veriyor? $(s) I$ 'yla çekimlenmiş bir yapının bu okumaya yol açmasının sebebi söz konusu yapının dahil olduğu ortamda 1 . ve 2 . kișili sahiplerin bulunmayıșıdır: geriye kalan tek seçenek 3. kişidir. $\mathrm{Bu}$ da aitlik ekinin 3. tekil kişi aitlik ekiymiş gibi algılanmasına sebep olmaktadır. 


\subsection{Kişiden Bă̆ımsız Aitlik}

$\mathrm{Bu}$ bölüm, aitlik kavramının sahip varlık ve ait varlık arasındaki ilişkiyi yansitmakla kalmayıp, kimi dillerde bir ulam olarak dilbilgisine girdiğini göstermeyi amaçlamaktadır. Aitlik bu çalışmanın savunduğu gibi özerk bir ulamsa, o zaman kişi ulamından bağımsız olarak gösterilebilmesi beklenir. Aşağıdaki Denesulinece (Dëne Sųłıné, Chipewyan) ${ }^{19}$ diline ait örnekler bu beklentiyi karşılamaktadır:

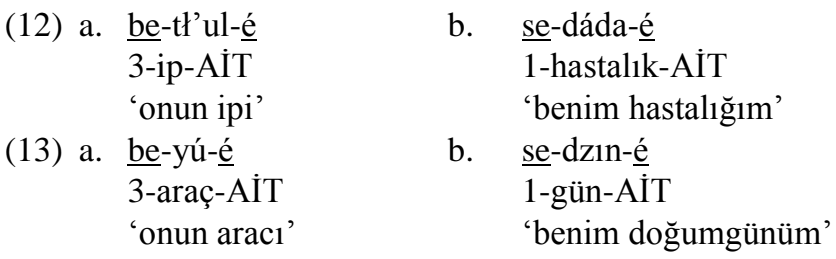

(Örnekler Saxon ve Wilhelm, 2011'den alınmıştır, örn. (6) ve (18))

Yukarıdaki Denesulinece ifadeler şu açıdan çok önemlidir: Bu dilde bir aitlik eki vardır, -é, ve bu ek tüm kişilerle belirebilmektedir, yani kişiden bağımsızdır. (12a, 13a)'da aitlik -é sonekiyle, 3. kişi de be- önekiyle, (12b, 13b)'de de aitlik yine -é sonekiyle, 1 . kişi ise $s e$ - önekiyle gösterilmektedir. ${ }^{20}$ Denesulinecedeki bu durum bir dilde yalnızca aitlikten sorumlu biçimbirimlerin olabileceğini göstermekte ve bu sebeple Türkçede $-(s) I$ ekinin sadece aitlik eki olduğu savını desteklemektedir.

$\S 3.1$ 'de önerilen ve $\$ 3.2$ 'de desteklenen çözümlemeye sorunmuş gibi duran bir nokta vardır: $-(s) I$ ekinin 1.AİT/2.AİT ekleriyle birlikte oluşamaması (bkz. (2)). Diğer bir deyişle, eğer $-(s) I$ kişisiz aitliği kodluyorsa, örneğin Denesulinecedeki aitlik eki gibi, $-(s) I$ 'nın da 1.AİT/2.AİT ekleriyle eklenebilmesi beklenirdi. Ancak Türkçede bu durum mümkün değildir, örn. *şarkl-sl-m/n ('şarkım', 'şarkın' için). Bu durumun açıklaması da şu şekildedir: Türkçedeki 1.AİT/2.AİT ekleri yalnızca kişi değil aynı zamanda aitlik ekleridir; bilindiği üzere, iyelik öbeklerindeki sahip ögeler olmadan da bu eklerle aitlik ifade edilebilmektedir, örn. şarkı- $-\underline{m} / \underline{n}$. Bu sebeple bu ekler birikim ekleridir (İng. "cumulative"): İki anlamı (kişi+aitlik) birden ifade etmek için kullanılırlar. Bu sebeple bu ekler kendileri gibi bir aitlik eki olan ancak birikim eki olmayan - $(s) I$ 'yla dizilsel bir zıtlık içindedirler: Aynı konum için yarışırlar

19 Kuzeybatı Kanada'da konuşulan bir Atabask dilidir.

20 Denesulinecede olduğu gibi bir Karayip dili olan "Carib"de de aitlik kişiden ayrı gösterilmektedir: Aitlik eki tüm kişilerle birlikte belirebilmektedir, bkz. Hoff, 1962. 
ve yan yana oluşamazlar. Daha az bilgiyi ifade etmek için kullanılan $-(s) I$ bu eklerin varlığında beliremez. ${ }^{21}$

\section{3 İyelik Öbeklerinin Kuruluşu ve Çekimlenişi}

Bu bölüme kadar - $(s) I$ 'nın işlevinin ne olduğu ve ne olamayacağı savunuldu. $\mathrm{Bu}$ bölümde de bu ekin nasıl eklendiği ve aitlik işleviyle nasıl eşleştiğini gösteren bir model sunulmaktadır (bu model Kundurac1, 2013'ün dizgesine dayalıdır). -(s)I'nın eklenmesi iyelik öbeklerinin yapısıyla da ilgili olduğundan önerilen model bu öbeklerin oluşumunu ve sonrasında aitlik eklerinin biçimbilimsel olarak eklenmesini içeren üç adımlık bir türetimden oluşmaktadır. ${ }^{22}$ Şimdi Kaan'ın şarkı-sı gibi bir iyelik öbeğinin bu modelle nasıl oluştuğuna bakalım:

\begin{tabular}{|c|c|c|c|}
\hline Adım: & $\begin{array}{l}{[\text { Kaan }+ \text { şarkı ] }} \\
\text { ILGİ ('Kaan', 'şark1') }\end{array}$ & $\rightarrow$ & $\begin{array}{l}\text { Sözdizim + Anlambilim: } \\
\text { Öbek }+ \text { Anlam Oluşumu }\end{array}$ \\
\hline Adım: & [Kaan-nın $\quad$ şarkl $]$ & $\rightarrow$ & $\begin{array}{l}\text { Biçimbilim + Anlambilim: } \\
\text { Sahip Ögenin Çekimi }\end{array}$ \\
\hline Adım: & [Kaan-nın & , & $\begin{array}{l}\text { Biçimbilim + Anlambilim: } \\
\text { Ait Ögenin Çekimi }\end{array}$ \\
\hline
\end{tabular}

Şekil 1. Türkçede 3. Kişili İyelik Öbeklerinin Oluşumu

Şekil 1'de göstreilen üç adımlık türetimin ilk adımı sözdizimsel bir operasyonu, yani ad öbeği oluşumunu ve öbek oluşumuyla eşleşen anlambilimsel bir kuralı içerir. [Kaan şarkı] öbeğinin içerdiği anlambilimsel kural yukarıda İLGi ('Kaan', 'şarkı') şeklinde gösterilmiştir. Bu kural iki üyeli bir fonksiyonun, ILGİ, iki ögenin anlamlarına uygulanıp, aralarında bir ilgi ilişkisi kurması şeklindedir. Bu tarz bir ilişki, yani ilgilendirme, sıradan ad öbeklerindeki

21 Türkçede 1.AİT/2.AİT ekleri gibi birikim eki olan başka ekler de vardır, örn. koş-tu$k$ ve $k o s ̧-s a-k$ biçimlerindeki $-k$ eki hem kişi hem de sayı değerlerini göstermektedir: ' 1 ', 'çoğul'. Bu durumda Türkçe gibi tipik olarak eklemeli ve anlam ve biçim arasında çoğunlukla bire bir eşleşme gösteren dillerde de birikim eklerinin olabileceğini görüyoruz. (Bu noktayı sorgulayan eleştirmene teşekkür ederim.)

$22 \S 1$ 'de de bahsedildiği gibi, bu çalışmada biçimbilimin sözdizim ve sözlükçeden ayrı, özerk bir bileşen olduğu varsayılmakta ve süreçsel biçimbilim çerçevesinde bir öneri sunulmaktadır. Süreçsel biçimbilim modellerinde, ekler ne sözlüksel birimler gibi sözlükçede ne de sözdizimsel ögeler gibi ağaçlarda gösterilir, örn, bkz. Zwicky, 1986; Aronoff, 1994; Beard, 1995; Pounder, 2000; Kundurac1, 2013. Bu yaklaşımda ekler biçimbilimseldir ve biçimbilimsel operasyonlara aittir. Bu sebeple bu çalışmada $-(s) I$ eki ve diğer aitlik ekleri biçimbilimsel olarak çözümlenmektedir. Bu ekleri sözdizimsel olarak inceleyen çalıșmalar için örn. bkz. Dede, 1978; George ve Kornfilt, 1981; Kornfilt, 1984b; Yükseker, 1994; Yükseker, 1998; Uzun, 2001; Arslan-Kechriotis, 2006; Yavuz, 2006; Tuğcu, 2009; Kharytonava, 2011. 
olağan anlamsal ilişkiden farklıdır, örn. eski şarkı $\rightarrow$ ESKİ('şarkı'). ${ }^{23}$ Kısaca birinci adım sonunda, iki üyesi, yani sahip ve ait ögelerin anlamı, arasında ilgi ilişkisi olan bir iyelik öbeği kurulmuş olur. ${ }^{24}$ Öbek oluşumu ve anlamsal birleşmeyi izleyen ikinci adım ise biçimbilimsel bir operasyonu içerir: sahip ögenin - $(n)$ In ekiyle çekimi ve tamlayan durumunu alması. Bu adım sonucundaki biçim Kaan- $\underline{\imath}$ şarkı şeklindedir. Son adıma gelince, burada da iyelik öbeğindeki diğer öge, ait/baş öge, yine biçimbilimsel bir operasyon içinde aitlik eki -(s)I ile çekimlenir ve Kaan-ın şarkl-ş biçimi elde edilir.

Görüldügü gibi Şekil 1'deki türetim modeli, biçimbilimi özerk bir bileşen olarak kabul etmektedir: Bu görüşte biçimbilimsel operasyonların Şekil 1'de olduğu gibi sözdizimsel operasyonları takip etmesine hiçbir engel yoktur (biçimbilimsel operasyonlar sözlükçede gerçekleşmez). ${ }^{25}$ Biçimbilimsel operasyonlar, aynı zamanda, sözdizime de ait değildir, örn. bkz., Beard, 1995; Pounder, 2000; Sadock, 2012; Kundurac1, 2013. Biçimbilimsel operasyonlara ait olan $-(s) I$ ve $-(n) I n$ eklerinin eklenmesi hem öbeksel hem de anlamsal birleşimden (1. Adım) sonra gerçekleşmektedir. Bu demektir ki bu iki ek ne sözdizimsel öbek yapısından ne de bu öbeğe ilgi ilişkisinin dahil edilmesinden sorumludur. $\mathrm{Bu}$ ekler yalnızca iyelik öbeğinin biçimbilimsel işaretleridir: Önceki aşamada kurulan ilgi ilişkisindeki sahip ve ait ögeleri gösterirler. Bu sebeple, bu türetimde biçimbilimsel ve sözdizimsel bileşenlerin olduğu gibi, anlambilimsel bileşenin rolü de büyüktür: İyelik öbeğindeki ilgi ilişkisinin sorumlusu anlambilimsel bileşendir, yani bu bileşene ait bir kuraldır.

$\mathrm{Bu}$ şekildeki bir türetimin şu şekilde olumlu getirileri vardır: Öncelikle böyle bir model, yani iyelik öbeklerindeki ögeler arası anlamsal ilişkiyi tamlayan ve aitlik eklerine yüklemeyen bir model, hem Türkçedeki hem de ilgi/aitlik ilişkisini biçimbilimsel olarak göstermeyen dillerdeki iyelik öbeklerini açıklayabilir. Örneğin Jamaika Kırma anadilinde (Jamaican

23 eski şarkl gibi bir ad öbeğinin göndergesi hem ilk ögenin hem de ikinci ögenin anlamını kesişimsel olarak içerir, yani ' $x$ ' hem 'eski' hem de 'şarkı'dır. İyelik öbeklerinde ise böyle bir niteleme yerine ilgisel bir niteleme vardır. Sıradan ad öbeklerindeki ilişkiler için önerilen anlamsal kurallar (fonksiyon uygulama ("function application"), yüklem niteleme ("predicate modification”)) için bkz. Heim ve Kratzer, 1998.

24 İyelik öbeklerindeki bu fonksiyonun, örneğin aitlik ya da sahiplik yerine, "ilgi" olarak değerlendirilmesinin sebebi iki öge arasında aitlik olmasa da daima (bir tür) ilgilendirme içeren bir ilişkinin bulunmasıdır. Örneğin Kaan'ın hediyesi öbeğinde, Kaan'a AİT bir hediyeden, Kaan İÇíN olan bir hediyeden, ya da Kaan'la İLGİsi olan bir hediyeden bahsediliyor olabilir. Türkçede iyelik öbeklerindeki anlamlar için ayrıca bkz. Kundurac1, 2013.

$25 \mathrm{Bu}$ çalışmadaki varsayıma göre, biçimbilimsel operasyonlar gerektiğinde sözdizimsel operasyonlardan önce, gerektiğinde sonra gerçekleşebilir. Özerk biçimbilim çerçevesinde, bileşenler arası etkileşime farklı yaklaşımlar için örneğin bkz., Zwicky, 1984; Beard, 1995; Sadock, 2012. 
Creole), iyelik öbeklerinin iki ögesinde de herhangi bir biçimbilimsel işaret yoktur; ait ve sahip ögeler sadece sözcük sırası sayesinde anlaşılır, bkz. (14):

(14) Rabat miizl

Rabat k1zamık

'Rabat'ın kızamığ 1 '

(Örnek Ultan'dan (1978, s. 16) alınmıştır.)

(14)'te ne sahip ögede ne de ait ögede herhangi bir biçimbilimsel işaret vardır; yine de öbekte ilgi ilişkisi vardır (Şekil 1'deki ilk adımdaki (gibi bir) anlambilimsel kural uygulanmıştır). Yine Türkçenin aksine, kimi dillerde iyelik öbeklerinde yalnızca ait öge işaretlenmektedir, örneğin Paama Dilinde (Paamese) zorunlu iyelik öbeklerinde olduğu gibi: ${ }^{26}$

(15) vati-n $\underline{n}$ èhon

baş-3.TEK çocuk

'çocuğun başı'

(Örnek Crowley'den (1996, s. 389) alınmıştır.)

Kimi dillerde ise yalnızca sahip öge için biçimbilimsel bir kodlama mümkündür, İngilizcede ya da (16)'da gösterildiği gibi Polonyacada olduğu gibi:

(16) torba Jan- $\underline{a}$

çanta Jan-TAM

'Jan'ın çantası'

(Örnek Siewierska'dan (2001, s. 139) alınmıştır.)

$\mathrm{Bu}$ bölümde şimdiye dek gördüğümüz örnekler bize iyelik öbeklerindeki anlamsal ilişkinin daima iki öge üzerinde (Türkçede olduğu gibi) değil, tek bir öge üzerinde de (bkz. $(15,16)$ ) biçimbilimsel olarak gösterilebildiğini, ya da biçimbilimsel olarak gösterilmeyebildiğini (bkz. (14)) göstermektedir. Bu da bizi iki öge arasındaki anlamsal ilişkinin bireysel eklerden bağımsız olduğu sonucuna ulaştırmaktadır, yukarıda Şekil 1'de önerildiği gibi. Bu modelin şöyle bir olumlu getirisi daha vardır: Türkçede günlük konuşmalarda $-(s) I$ ve diğer aitlik eklerinin iyelik öbeklerinde, aşağıda (17)'de örneklendiği gibi, kullanılmaması açıklanabilmektedir.

26 Bu dil, Büyük Okyanus'un güneyinde Vanuatu Cumhuriyeti'nde konuşulan bir dildir. 
(17) a. Kaan-1n ev

b. ben-im ev

c. sen-in ev

1.AİT, 2.AİT ve $-(s) I$ eklerinin (17)'de olduğu gibi eklenmeyebilmesi bu eklerin gerek sözdizimsel öbek yapısından gerekse anlamsal ilişkinin kurulmasından sorumlu olamayacağını göstermektedir. Diğer bir deyişle, iyelik öbeklerindeki öbek yapısı ve anlam, bu ekler biçimbilim tarafından eklenmeden önce edinilmiş olmalıdır.

Şekil 1'deki modelin olumlu getirilerine değindikten sonra şimdi de aitlik ekinin ve tamlayan ekinin eklenme süreçlerini, yani modelin ikinci ve üçüncü adımlarını daha yakından inceleyelim. Bu çalışmada bu eklenme süreçleri için önerilen çözümleme Kunduracı, 2013'e dayanmaktadır. Bu çözümleme süreçsel biçimbilim yaklaşımını izlemekte (bkz. Dipnot 22) ve Süreç-Dizil (Process and Paradigm), Pounder, 2000 çerçevesini kullanmaktadır. Öncelikle, Şekil 1'deki ikinci adıma, yani tamlayan eki -(n)In'ın eklenmesinden sorumlu olan biçimbilimsel operasyona bakalım:

... 2. Adım:

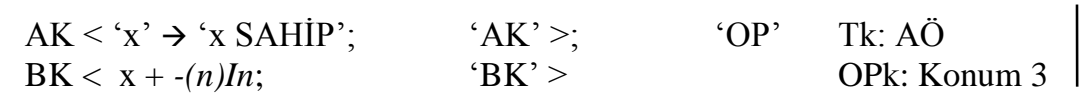

\section{Şekil 2. Türkçede Tamlayan Ekinin Eklenişi}

Şekil 2 biçimbilimsel bir operasyonu ifade etmektedir: $\mathrm{Bu}$ operasyonda birbiriyle eşleşen/örtüsşen ve " $<\ldots$.. içinde gösterilen bir anlamsal (anlambilimsel) bir de biçimsel (biçimbilimsel) kural vardır, kısaca AK ve BK olarak gösterilmektedirler. Anlamsal Kural, ilk adımda kurulan ILGí ilişkisindeki (bkz. Şekil 1, Adım 1) ilk üyenin niteleyen, yani sahip öge, olduğunu ifade eder. BK, yani biçimsel kural ise $-(n)$ In ekinin eklenmesi ve durum çekiminden sorumludur. $\mathrm{Bu}$ iki kuralın eşleşmesi Şekil 1'deki biçimbilimsel operasyonun ilk kısmını oluşturur. Operasyonun ikinci kısmında gösterilen 'OP', bu operasyonun Türkçedeki biçimbilim dizgesinde bir yeri olduğunu ifade etmektedir. Bu operasyonun ad öbeklerine, yani AÖ tabanlara, uygulandığını gösteren bir Taban Koşulu $(\mathrm{Tk}),{ }^{27}$ ve ilgili ekin sözcük

27 Taban koşulları, basitçe, biçimbilimsel operasyonlarda eklerin eklenebildiği taban türlerini göstermek için kullanılmaktadır. 
yapısındaki konumunu (Konum 3$)^{28}$ gösteren bir de Operasyon Koşulu (OPk) vardir.

Şimdi de aitlik eki $-(s)$ I'nın eklenmesinden sorumlu biçimbilimsel operasyona bakalım:

... 3. Adim:

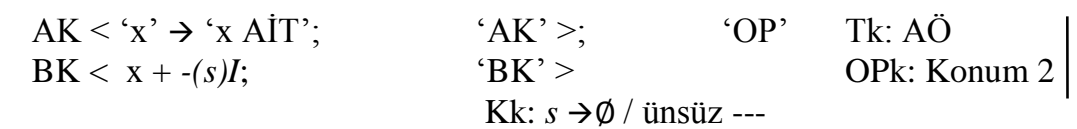

\section{Şekil 3. Türkçede Aitlik Ekinin Eklenişi}

Bu operasyondaki Anlamsal Kural, Şekil 1, Adım 1'de kurulan İLGi ilişkisinin ikinci üyesi olan nitelenen ögeyi, yani ait ögeyi ifade eder ve $-(s) I$ ekini ekleyen Biçimsel Kural ile eşleşir. Biçimsel kuralın bir kural koşulu $(\mathrm{Kk})$ vardır: $-(\underline{s}) I$ ekindeki ünsüz, ünsüzlerle biten tabanların ardından belirmemektedir. ${ }^{29} \mathrm{OP}$, bu operasyonun Türkçe biçimbilim dizgesinde bir yeri olduğunu, Tk bu operasyonun ad öbeklerine uygulandığını ve OPk de aitlik ekinin Konum 2'ye eklendiğini göstermektedir (bkz. Dipnot 28).

Böylece, Türkçedeki 3. kişili iyelik öbeklerinin, -(s)I'nın eklenmesinin de dahil olduğu biçimsel ve anlamsal çözümlemelerini bitirmiş olduk. Şimdi de 1. ve 2. kişili iyelik öbeklerinde 1.AİT/2.AİT eklerinin eklenmesine bir göz atalım. Bu çalışma 1. ve 2. kişili iyelik öbeklerinin de Şekil 1'deki adımlarla türediğini, ancak 3. adımda bir değişiklik içerdiğini öne sürmektedir. 3. kişili iyelik öbeklerinden farklı olarak, bu kez son adımda aitlik eklerinin (1. AİT/2.AIT) eklenmesiyle iki öge arasında kişi ve sayı değerlerini içeren bir uyum ilişkisi de kurulmaktadır. Son adımdaki bu değişikliği, aşağıda Şekil 4'te ben-im şarkl-m örneği üzerinden görmekteyiz:

28 Tamlayan ekinin Konum 3'te olması, bir durum eki olmasındandır: Tabanı hemen izleyen Konum 1 sayı çekimi için, Konum 2 aitlik/iyelik ekleri için ve Konum 3 de durum ekleri için ayrılmıştır, örn. ev-ler-im- $\underline{\text { de }}$.

29 Bu çalışmadaki yaklaşıma göre, biçimbilimsel bir operasyonun sonunda biçimbilim kaynaklı sesbilimsel değișiklikler gerekebilir, yukarıdaki Kk'de olduğu gibi. Bu da bize biçimbilimsel bileşenin sözdizim ve anlambilimle olduğu gibi, sesbilimle de yakın etkileșimler içinde olduğunu gösterir. Ancak, yukarıdaki Kk'deki gibi bir etkileșim içermeyen, yalnızca sesbilim kaynaklı koşullar da vardır, örneğin - $(s) I$ ekindeki kapalı ünlünün, eklendiği tabanla önlük/artlık ve yuvarlaklık açısından uyuşması. 


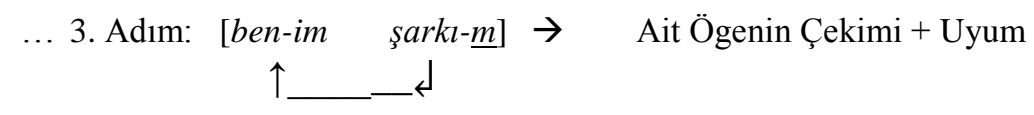

Şekil 4. Türkçede 1. ve 2. Kişi Aitlik Eklerinin Eklenişi

Bu şekille anlatılmak istenen şudur: Türkçe iyelik öbeklerinde uyum yalnızca 1. ve 2. kişi değeriyle mümkündür. Şekil 4 'te uyum ilişkisinin dayandığı kişi değeri ' 1 'dir, bu değer uyum ilişkisindeki denetici olan sahip ögeden, ilişkideki hedef olan ait ögeye aktarılır. ${ }^{30} \mathrm{Bu}$ ilişki, uyum, biçimbilimsel olarak aitlik-kişi ekleriyle ifade edilir (1.AİT ya da 2.AİT). $\$ 2$ ve $\S 3.1$ 'den hatırlanacağı gibi, 1.AİT ve 2.AİT ekleri aitlik olduğu kadar kişi ulamını da ifade eden birikim ekleridir. Bu da şu anlama gelmektedir: Bu iki ek, $-(s) I$ 'nın aksine, uyum ekidir. Aşağıda §4’te, bu sav, yani aitlik ulamının uyum ilişkisiyle birlikte gösterildiği gibi, uyum olmadan da gösterilebileceği, desteklenmektedir.

\section{Uyumsuz Aitlik}

Yukarıdaki bölümde Türkçede, 1. ve 2. kişili iyelik öbeklerinin aksine, 3. kişili iyelik öbeklerinin uyum içermediği savunuldu. Bu sav, çalışmanın $-(s) I$ 'nın 3. tekil kişi iyelik/aitlik değil yalnızca aitlik eki olduğu önerisine dayanmaktadır (bkz. §2, §3.1). Daha açık olmak gerekirse, -(s)I kişi değeri kodlamadığı için, 3. kişili iyelik öbeklerinde uyum ilişkisinin dayanacağ 1 bir kişi değeri de olmayacak ve bu da ne kişi ne de sayı uyumuna izin vermeyecektir, §2'de açıkça gösterildiği gibi. Bu bölüm bu sava iki farklı dilden destek sunmaktadır. Yani, başka dillerde de uyum içermeyen iyelik öbeklerinin kurulabildiği gösterilmektedir.

Öncelikle, Tauya Diline bakalım: ${ }^{31}$ Siewierska (2004, s. 138) bu dilde atılabilir iyelik ${ }^{32}$ içeren iyelik öbeklerinin kişi-sayı uyumu içermediğini öne sürmüştür, aşağıda (18)'de örneklendiği gibi. Görüldüğü gibi, (18)'deki iyelik öbeklerindeki tamlayan ekiyle çekimlenmiş sahip ögeler kişi ve sayı değerleri içerse de, bu değerler öbeklerdeki altı çizili baş/ait ögelerde gösterilmemektedir:

\footnotetext{
30 Bu çalışma, Corbett, 2001, 2006 ve Cysouw, 2011'de olduğu gibi uyumun öbekler arasında kurulan bir tür "ilişki" olduğunu varsaymakta ve Corbett'in uyuma dair terimlerini kullanmaktadır (controller 'denetici', target 'hedef').

31 Tauya, Papua Yeni Gine'de konuşulan bir dildir.

32 "atılabilir iyelik" (alienable possession), "zorunlu iyeliğin” (inalienable possession) aksine, sahip ve ait öge arasındaki geçici, dıştan gelen türden bir iyeliği ifade etmektedir.
} 


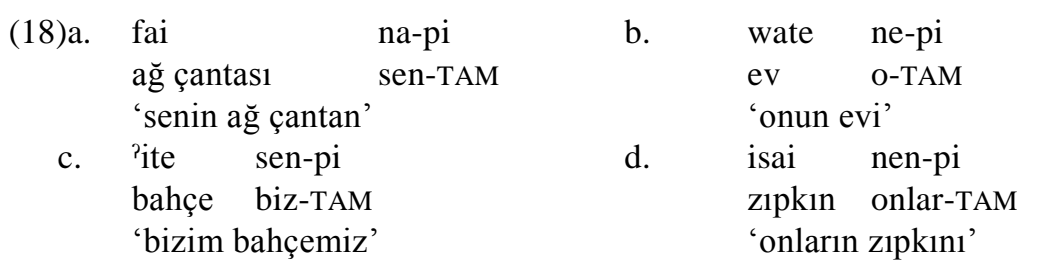

(Örnekler MacDonald, 1990’dan alınmıştır (s. 131).)

(18a)'da fai üzerinde 2. tekil kişi, (18b)'de wate üzerinde 3. tekil kişi, (18c)'de 'ite üzerinde 1. çoğul kişi ve (18d)'de de isai üzerinde 3. çoğul kişi gösterilmemektedir: Yani bu öbekler aitlik içermekte ancak kişi ya da sayı uyumu içermemektedir. Bu değerler yalnızca sahip ögelerde (adıllarda, sırasıly na, ne, sen ve nen) bulunmakta ve ait ögelere aktarılmamaktadır.

Şimdi de Tundra Nenets Diline ${ }^{33}$ bakalım: Nikolaeva'nın (2005) belirttiği gibi, bu dildeki iyelik öbeklerinde ait ögede kişi uyumu sahip ögeler adıl olduğunda zorunluyken (19a), sahip ögeler adıl değilse uyum görülmez (19b):

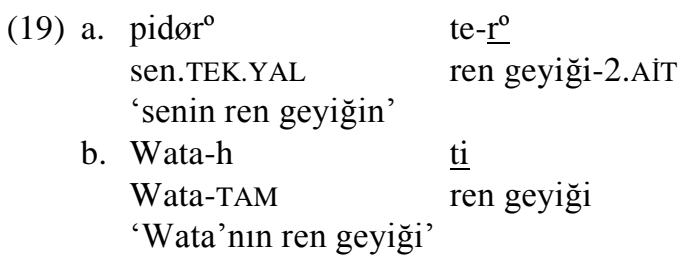

(Örnekler Nikolaeva’dan (2005, s. 223) alınmıştır.)

(19b)'deki ifade, Tundra Nenets Dilinde belli bir takım iyelik öbeklerinin uyum olmadan kurulduğunu göstermektedir: (19a)'daki ait ögenin aksine (ter 'ren geyiğin'), (19b)'deki $t i$ 'ren geyiği' herhangi bir kişi değeri ve uyumu göstermemektedir.

Bu bölümde değinilen örnekler, kısaca, bazı iyelik öbeklerinde uyumun zorunlu olduğu gibi, diğerlerinde uyumun olmadığını göstermekte ve dolayısıyla Türkçedeki 3. kişili iyelik öbeklerinin uyumsuz kurulmasının hiç de sıradışı bir durum olmadığını ortaya çıkarmaktadır.

\section{Sonuçlar}

Bu çalışmada Türkçede iyelik öbeklerinde beliren $-(s) I$ ekinin hemen hemen tüm alanyazında kabul edilen 3. tekil kişi işlevine karşı bir tartışma sunulmuş, (s)I'yla kişi ve sayı yerine aitlik ulamının bir değeri eşleştirilmiştir: 'ait'.

33 Tundra Nenets bir Kuzey Samoyed dilidir. 
Önerilen çözümlemeyle sadece $-(s) I$ 'nın oluşumu değil oluşması beklendiği halde oluşmadığı durumlar, biçimbilimsel olarak kısıtlılığı ve diğer aitlik eklerinden hangi noktada ayrıldığı da açıklanmıştır. Aitliğin Türkçede bir ulam olduğunu savunan çalışma, aynı zamanda, iyelik öbeklerinde kişi ve sayı uyumuna değinerek, 3. kişiyi içeren iyelik öbeklerinde, 1. ve 2. kişiyi içerenlerin aksine, ne kişi ne de sayı uyumu olamayacağını göstermiştir. Buradan da $-(s) I$ ekinin Türkçede bir uyum eki olmadığı sonucuna varılmıştır. Çalışmadaki savlar ve çözümleme Türkçe dilbilgisinin 3. kişi değerine genel davranışıyla örtüşmektedir ve Türkçeyle herhangi bir bağlantısı olmayan kimi dillerdeki ilginç verilerle desteklenmiştir.

Çalışmada ayrıca Türkçedeki iyelik öbeklerinde kişi uyumu gerçekleşmeden sayı uyumunun da gerçekleşmediği gözlemlenmiştir. Bu durumun, yani iyelik öbeklerinde sayı uyumunun kişi uyumuyla koşullanmasının, farklı dillerde de incelenmesinin bu iki ulamla ilgili daha ilginç, belki evrensel kimi özellikleri ortaya çıkarabileceği düşünülmektedir.

Diğer bir sonuç da biçimbilimsel birikme ile ilgilidir: Kişi ve aitlik ulamları kimi dillerde birikmeyle ifade edilse de, diğerlerinde böyle bir birikimin zorunlu olmadığı, aitliğin kişiden ve uyumdan ayrı, bağımsız olarak gösterilebileceği ortaya çıkmıştır.

Önerilen çözümlemeyle aynı zamanda $-(s) I$ ekinin ad-ad tabanlı bileşik sözcüklerdeki, örn. opera şarkl-sl, oluşumuna da doğrudan bir gönderme yapmak ve iyelik öbekleri ve bu türden sözcük yapıları arasında "kişi”" yerine "aitliğe” dayanan bir köprü kurmak da mümkündür (bkz. Kundurac1, 2013).

Son olarak da bir takım kuramsal çıkarımlara değinmek gerekir: Önerilen çözümlemede dilbilgisinde özerk bir biçimbilim olduğu varsayılmaktadır. Yukarıda iyelik öbekleri için önerilen modelde biçimbilimsel operasyonlar sözdizimsel operasyonları izlemektedir; ekler tek başına anlamdan sorumlu değildir; ekler öbek yapı oluşumundan da sorumlu değildir. Bu şekilde hem aitlik eklerinin neden oluştuğu hem de neden eklenmeyebildiği açıklanabilmektedir (bkz. (17)). Örneğin, eklere biçimbilimsel yerine sözdizimsel çözümlemeler öneren yaklaşımlar (Halle ve Marantz, 1993; Baker, 1998; Harley, 2009 gibi) aitlik eklerini (ve diğer ekleri) sözdizimsel konumlara oturtacağından, bu eklerin beklendiği halde eklenmediği durumları açıklamakta zorlanacaktır. Diğer bir taraftan, eklere ve biçimbilime sözlüksel kimlikler yükleyen yaklaşımlar da (örn. Lieber, 1980; Jensen ve Jensen, 1984; Giegerich, 1999) aitlik eklerine (ve diğer eklere) bire bir anlamlar yükleyeceğinden, yine bu eklerin olmadığı ama aitlik/ilgi ilişkisinin buna rağmen kurulabildiği durumları açıklamakta zorlanacaktır. Oysa ki bu çalışmada olduğu gibi, ekler, eklenmeler (ve diğer biçimbilimsel süreçler) özerk biçimbilim yaklaşımıyla değerlendirildiğinde, aşırı soyutlanma ve koşullanmalara gerek kalmadan, eklerin varlığı da yokluğu da sorunsuzca açıklanabilir, biçimbilimsel birimler, hem sözlüksel hem de sözdizimsel 
birimlerden ayırt edilerek, dilbilimsel olgulara daha gerçekçi ve somut açıklamalar sunulabilir.

\section{Kaynaklar}

Anderson, S. R. (1992). A-morphous morphology. Cambridge: Cambridge University Press.

Aronoff, M. (1994). Morphology by itself: Stems and inflectional classes. Cambridge: MIT.

Arslan-Kechriotis, Z. (2006). Case as an uninterpretable feature. Ph.D Dissertation, Boğaziçi University.

Baker, M. (1998). Comments on the paper by Sadock. In S. Lapointe, D. Brentari, and P. Farrell (Eds.), Morphology and Its Relation to Phonology and Syntax (pp.188212). Standford: CSLI Publications.

Beard, R. (1995). Lexeme-morpheme base morphology. Albany: State University of New York Press.

Corbett, G. G. (2001). Agreement: terms and boundaries. In W. Griffin (Ed.), Proceedings of the 2001 Texas Linguistic Society Conference: The Role of Agreement in Natural Language (pp.109-122). Austin, Texas: Texas Linguistic Society.

Corbett, G. G. (2006). Agreement. Cambridge: Cambridge University Press.

Crowley, T. (1996). Inalienable possession in Paamese grammar. In H. Chappel and W. McGregor (Eds.), The Grammar of Inalienability (pp.384-464). Berlin: Mouton de Gruyter.

Cysouw, M. (2011). Very atypical agreement indeed. Theoretical Linguistics, 37, 153160.

Dede, M. (1978). A syntactic and semantic analysis of Turkish nominal compounds. Ph.D Dissertation, University of Michigan.

Di Sciullo, A., and Williams, E. (1987). On the definition of word. Cambridge: MIT.

George, L., and Kornfilt, J. (1981). Finiteness and boundedness in Turkish. In F. Heny (Ed.), Binding and Filtering (pp.104-127). London: Croom Helm; Cambridge, Mass: MIT.

Giegerich, H. (1999). Lexical strata in English: Morphological causes, phonological effects. Cambridge: Cambridge University Press.

Göksel, A. (1998). Word size. In G. Booij, A. Ralli, and S. Scalise (Eds.), Proceedings of the First Mediterranean Conference on Morphology (pp.190-200). Patras: University of Patras.

Göksel, A., and Kerslake, C. (2005). Turkish: A comprehensive grammar. London:Routledge.

Haig, G. (2004). Constraints on morpheme repetition in Turkish? In K. Imer and G. Dogan (Eds.), Current Research in Turkish Linguistics (pp.3-12). Gazimagusa: Eastern Mediterranean University Press.

Halle, M., and Marantz, A. (1993). Distributed morphology and the pieces of inflection. In K. Hale and S. Keyser (Eds.), The View from Building 20: Essays in Linguistics in Honor of Sylvain Bromberger (pp.111-176). Cambridge, Massachusetts: MIT.

Hankamer, J. (2011). Turkish vowel epenthesis. In E. Erguvanl1-Taylan and B. Rona (Eds.), Puzzles of Languages: Essays in Honour of Karl Zimmer (pp.55-69). Harrassowitz Verlag: Wiesbaden. 
Harley, H. (2009). Compounding in distributed morphology. In R. Lieber and P. Stekauer (Eds.), The Oxford Handbook of Compounding (pp.129-144). Oxford: Oxford University Press.

Heim, I., and Kratzer, A. (1998). Semantics in generative grammar. Oxford: Blackwell.

Hoff, B. (1962). The nominal word-groups in Carib: A problem of delimitation of syntax and morphology. Lingua, 11, 157-164.

Jensen, J., and Stong-Jensen, M. (1984). Morphology is in the lexicon! Linguistic Inquiry, 15, 474-98.

Kharytonava, O. (2011). Noms composés en Turc et morphème - $(s) I$. Ph.D Dissertation, The University of Western Ontario.

Kornfilt, J. (1984a). The stuttering prohibition and morpheme deletion in Turkish. InE. Erguvanl1-Taylan and A. Aksu-Koç (Eds.), Proceedings of the Turkish Linguistics Conference (pp.295-307). Istanbul: Boğaziçi University Publications.

Kornfilt, J. (1984b). Case marking, agreement, and empty categories in Turkish.Ph.D Dissertation, Harvard University.

Kornfilt, J. (1997). Turkish grammar. London: Routledge.

Kundurac1, A. (2013). Turkish noun-noun compounds: A process-based paradigmatic account. $\mathrm{PhD}$ Dissertation, University of Calgary.

Lewis, G. (1967). Turkish grammar. Oxford, New York: Oxford University Press.

Lewis, G. (2000). Turkish grammar (2nd ed.). New York: Oxford University Press.

Lieber, R. (1980). On the organization of the lexicon. Ph.D Dissertation, University of New Hampshire.

MacDonalds, L. (1990). A grammar of Tauya. Berlin: Mouton de Gruyter.

Mel'čuk, I. (1994). Cours de morphologie générale 2. Montréal, Paris: Les Presses del'Université de Montréal.

Nikolaeva, I. (2005). Modifier-head person concord. In G. Booij, E. Guevara, A. Ralli, S. Sgroi, and S. Scalise (Eds.), Morphology and Linguistic Typology: Online Proceedings of the 4th Mediterranean Morphology Meeting (pp.221234),http://mmm.lingue.unibo.it.

Pounder, A. (2000). Processes and paradigms in word-formation morphology. Berlin:Mouton de Gruyter.

Sadock, J. M. (2012). The modular architecture of grammar. Cambridge: Cambridge University Press.

Saxon, L., and Wilhelm, A. (2011). Dene [Athabaskan] possessive compounds and thearchitecture of the grammar. Poster presented at the 8th Mediterranean Morphology Meeting, Cagliari.

Siewierska, A. (2004). Person. Cambridge: Cambridge University Press.

Tuğcu, P. (2009). Türkçede belirleyici öbeği. Yüksek Lisans Tezi, Ankara Üniversitesi.

Ultan, R. (1978). Toward a typology of substantival possession. In J. H. Greenberg (Ed.), Universals of Human Language 4 (pp.11-50). Stanford CA: Standford University Press.

Underhill, R. (1976). Turkish grammar. Cambridge: MIT.

Uzun, N. E. (2001). Anaçizgileriyle evrensel dilbilgisi ve Türkçe. İstanbul: Multilingual Yayınları.

Uzun, N. E. (2002). Türkçenin uyumsuz uyumları. Dil Dergisi, 115, 20-36.

van Schaaik, G. (1996). Studies in Turkish grammar. Turcologica 28. Wiesbaden: Harrassowitz.

Yavuz, M. A. (2006). The syntactic aspects of noun phrases in Turkish and the problems arising from the representations of NPs. In S. Yağcioğlu, A. C. Değer, Ö. Koşaner, and A. Çeltek (Eds.), Advances in Turkish Linguistics (pp.305-313). İzmir: Dokuz Eylül Yayınları. 
Yükseker, H. (1994). Possessive constructions in Turkish. In L. Johanson (Ed.), Proceedings of the Seventh International Conference on Turkish Linguistics (pp.458-477). Wiesbaden: Harrassowitz.

Yükseker, H. (1998). Turkish Possessive Compounds. In G. Booij, A. Ralli, and S. Scalise (Eds.), Proceedings of the First Mediterranean Conference on Morphology (pp.153-164). Greece: University of Patras.

Zwicky, A. M. (1984). Reduced words in highly modular theories: Yiddish Anarthrous locatives reexamined. Ohio State University Working Papers in Linguistics, 29, 117126.

Zwicky, A. M. (1986). The general case: basic form vs. default form. In D. Feder, M.Niepokuj, V. Nikiforidou, and M. van Clay (Eds.), Proceedings of the Annual Meeting of Berkeley Linguistics Society 12 (pp.305-314). Berkeley: Berkeley Linguistics Society. 